\title{
APLIKASI PERSAMAAN DIFERENSIAL PADA MODEL PERTUMBUHAN POPULASI DENGAN PERTUMBUHAN TERBATAS
}

\author{
Iswan Rina ${ }^{1 *}$, Radhiatul Husna ${ }^{2}$ \\ ${ }^{1}$ Universitas Dharma Andalas \\ ${ }^{2}$ Universitas Andalas \\ ${ }^{1}$ Jl. Sawahan No.103, Simpang Haru, Kec. Padang Timur, Kota Padang, Sumatera Barat \\ ${ }^{2}$ Jalan Limau Manis, Kec. Pauh, Kota Padang, Sumatera Barat \\ *Email: Iswanrina0@gmail.com
}

\begin{abstract}
Differential equations are one of the topics in mathematics that have many applications in mathematical modeling, for example in population growth. Population growth is an important thing that needs to be considered in order to be able to see the development of an area so that it can assist the regional government in determining the policies taken for the progress of the region related to the potential growth of the existing population. In this paper we will study population growth models with limited growth. From this model, the population of a region can be predicted in the coming year.
\end{abstract}

Keywords: Model, population growth, deferential equation.

\section{PENDAHULUAN}

Persamaan diferensial merupakan salah satu bagian menarik dalam matematika yang banyak digunakan pada percobaan matematika. Dalam hal ini persamaan diferensial melibatkan turunan yang dapat diinterprestasikan sebagai laju perubahan. Salah satu contohnya adalah laju perubahan populasi. Dari laju perubahan populasi tersebut dapat dikontruksi suatu model pertumbuhan populasi. Pertumbuhan populasi merupakan salah satu faktor penting yang harus diperhatikan untuk dapat melihat perkembangan suatu daerah sehingga dapat membantu pemerintah daerah tersebut, dalam mengambil kebijakan untuk kemajuan daerah.

Aplikasi persamaan diferensial ini telah banyak digunakan dalam permasalahan matematika terkait dengan pertumbuhan populasi, misalnya (Tsoularis \& Wallace, 2002) membahas mengenai analisis dari model pertumbuhan logistic. Selanjutnya (Law, Murrell, \& Dieckmann, 2003) mempelajari tentang pertumbuhan populasi pada ruang dan waktu dengan menggunakan persamaan logistik spasial. Dalam makalah ini akan dipelajari mengenai aplikasi persamaan diferensial pada model pertumbuhan populasi dengan pertumbuhan terbatas. Dari model tersebut dapat diprediksi jumlah populasi suatu daerah di tahun-tahun yang akan datang dengan mengambil contoh kasus pada populasi penduduk provinsi Sumatra Barat.

\section{Persamaan Diferensial}

Berikut ini akan diberikan beberapa hal terkait dengan persamaan diferensial. Persamaan diferensial adalah persamaan matematika dalam suatu fungsi satu variabel atau lebih yang menghubungkan nilai fungsi itu sendiri dan turunannya dalan berbagai orde. (Trench, 2013).

Dengan kata lain persamaan diferensial memuat satu atau lebih suku yang melibatkan turunan dari satu variable yaitu variable terikat , misalnya $y$ terhadap variable-variabel lain yakni variable bebas, misalnya $x$. Solusi dari persamaan diferensial berupa fungsi yang 
memenuhi persamaan tersebut. Persamaan diferensial banyak diaplikasikan dalam masalah - masalah pada bidang fisika, kimia, biologi, ekonomi, teknik dan ilmu-ilmu lainnya.

Orde dari suatu persamaan diferensial adalah turunan tertinggi yang muncul dalam persamaan tersebut.

Sebagai contoh: $\frac{d^{2} y}{d x^{2}}+2 \frac{d y}{d x}+y=0$ merupakan persamaan diferensial berorde dua.

Derajat dari dari suatu persamaan diferensial adalah pangkat dari orde persamaan diferensial tersebut.

Contohnya: $\left(\frac{d^{2} y}{d x^{3}}\right)^{3}-5\left(\frac{d^{2} y}{d x^{3}}\right)^{3}+2 x y=6 \quad$, merupakan persamaan diferensial biasa orde 3 berderajat 2 .

Secara umum persamaan diferensial dibagi dua yaitu:

1. Persamaan Diferensial Biasa (PDB) adalah persamaan diferensial yang melibatkan fungsi dari satu variabel dan beberapa turunannya dimana persamaan tersebut memuat masing-masing satu variabel terikat dan bebas.

Contohnya: $\frac{d y}{d x}=2 x$

2. Persamaan Diferensial Parsial (PDP) adalah persamaan diferensial yang melibatkan fungsi dari dua variabel atau lebih dan beberapa turunan parsialnya. Dalam hal ini persamaan diferensial tersebut memuat satu variabel terikat dari dua atau lebih variabel bebasnya.

Contohnya persamaan gelombang:

$\frac{\partial^{2} y}{\partial x^{2}}=c^{2} \frac{\partial^{2} u}{\partial x^{2}}$.

Berdasarkan kelinierannya, persamaan diferensial dibagi menjadi:

a. Persamaan diferensial linier yaitu persamaan diferensial yang dapat ditulis dalam bentuk

$a_{n}(x) \frac{d^{n} y}{d x^{n}}+a_{n-1}(x) \frac{d^{n-1} y}{d x^{n-1}}+\cdots+a_{1}(x) \frac{d y}{d x}+$ $a_{0}(x) y=f(x)$

Dari persamaan tersebut dapat dilihat karakteristik persamaan diferensial linier yaitu:
1. Variabel terikat y dan semua turunannya merupakan persamaan diferensial berderajat satu.

2. Masing-masing koofisien hanya bergantung pada variabel bebas $x$.

3. Tidak mengandung bentuk perkalian antara sebuah variabel terikat dengan variabel terikat lainnya.

Sebagai contoh:

1). PDB linier orde satu:

$(2 y-x) d x+x d y=0$

2). PDB linier orde 3 yaitu:

$x^{2} \frac{d^{3} y}{d x^{3}}-x \frac{d y}{d x}+6 y=e^{2 x}$

b. Persamaan Diferensial non Linier adalah persamaan diferensial adalah persamaan diferensial yang bukan persamaan diferensial linier.

Sebagai contoh :

1. $(2-y) \frac{d y}{d x}+2 y=e^{x}$, PDB non linier orde 1 . 2. $\frac{d^{2} y}{d x^{2}}+\sin y=0$, PDB non linier orde 2 .

(Giordano, Fox, \& Horton, 2010).

Salah satu cara untuk menyelesaikan suatu PDB orde 1 dapat dilakukan dengan metode pemisahan variabel yaitu dengan memisahkan variabelnya di dua ruas yang berbeda kemudian di integralkan kedua ruanya sehingga diperoleh solusinya. Metode ini dapat digunakan untuk persamaan diferensial dalam bentuk sebagai berikut:

$\frac{d y}{d x}=f(y) g(x)$,

dimana $f$ suatu fungsi dari $y$ saja dan $g$ hanya meupakan fugsi dari $x$.

Selanjutnya dinyatakan sebagai

$$
\frac{1}{f(y)} d y=g(x) d x
$$


sehingga dapat diintegralkan kedua ruasnya untuk mendapatkan solusinya berupa $y=$ $f(x)$.

\section{METODE PENELITIAN}

Langkah-langkah yang dilakukan dalam penelitian ini adalah sebagai berikut :

1) Memberikan penjelasan mengenai persamaan diferensial

2) Mengambil data sensus penduduk sumbar sebagai studi kasus

3) Mengidentifikasi masalah

4) Membuat asumsi dan mengkonstruksi model

5) Mencari solusi model dan menjelaskan interpretasi model

6) Melaukukan verifikasi model

7) Melakukan perbaikan model

\section{HASIL DAN PEMBAHASAAN}

Berikut ini akan dibahas aplikasi persamaan differensial pada pertumbuhan populasi penduduk, sehingga diperoleh suatu model pertumbuhan populasi dengan pertumbuhan terbatas.

a) Identifikasi masalah

Misalkan diketahui populasi pada suatu waktu $t$ sebagai contoh $P_{0}$ meyatakan jumlah populasi pada saat $t=t_{0}$. Dalam hal ini akan diprediksi jumlah populasi $P$ pada waktu yang akan datang yakni $t=t_{1}$. Dengan kata lain akan ditentukan suatu fungsi populasi $P(t)$ Untuk $t_{0} \leq t \leq t_{1}$ yang memenuhi $P\left(t_{0}\right)=$ $P_{0}$.

b) Asumsi dan kontruksi model

Sebagaimana yang diketahui banyak faktor yang mempengaruhi laju pertumbuhan pupolasi, seperti kelahiran, kematian, imigrasi, emigrasi dan lainnya. Dalam hal ini hanya dipertibangkan faktor kelahiran dan kematian karena seiring dengan kemajuan pengetahuan dan teknologi,manusia dapat mengurangi laju kematian dibawah laju kelahiran sehingga populasi penduduk menjadi cenderung meningkat.

Dengan mulai mengasumsikan bahwa selama suatu periode waktu yang singkat, yaitu misalkan a merupakan persentase laju kelahiran dan $b$ merupakan persentase laju kematian. Dengan kata lain, populasi baru $P(t+\Delta t)$ adalah populasi awal $P(t)$ ditambah banyaknya kelahiran kemudian dikurangi denagn jumlah kematian selama periode waktu $\Delta t$. Secara matematikanya hal ini dapat diulis sebagai berikut:

$$
\begin{aligned}
& \quad \begin{array}{l}
P(t+\Delta t)=P(t) \\
\quad \text { atau }
\end{array} \\
& \begin{aligned}
P(t+\Delta t)-P(t) & =\Delta P(t) \Delta t-b P(t) \Delta t \\
& =a P(t) \Delta t-b P(t) \Delta t
\end{aligned}
\end{aligned}
$$

Dengan membagi kedua ruas dengan $\Delta t$, maka diperoleh

$$
\frac{\Delta P}{\Delta t}=a P(t)-b P(t)=k P(t), \text { dengan } k>0
$$

Dari asumsi bahwa laju pertumbuhan rata-rata populasi terhadap suatu periode waktu, proporsional terhadap jumlah populasinya untuk memperkirakan laju perubahan rata- rata, digunakan laju perubahan sesaat sehingga diperoleh

$$
\frac{d P}{d t}=\lim _{\Delta t \rightarrow 0} \frac{\Delta P}{\Delta t}=k P
$$

Dengan demikian diperoleh suatu model persamaan differensial

$$
\frac{d P}{d t}=k P, P\left(t_{0}\right)=P_{0}, t_{0} \leq t \leq t_{1}
$$

c) Solusi dari interpretasi model

Dari model (1) dicari solusinya dengan metode pemisahan variabel sebagai berikut

$$
\begin{aligned}
& \quad \frac{d P}{d t}=k P \\
& \leftrightarrow \frac{d P}{P}=k d t \\
& \begin{array}{l}
\text { Dengan mengintegralkan kedua ruasnya } \\
\text { diperoleh : }
\end{array} \\
& \qquad \begin{array}{l}
\frac{d P}{P}=k d t \\
\qquad n P=k t+C \text { untuk suatu constanta } \mathrm{C} . .(2)
\end{array}
\end{aligned}
$$


Selanjutnya disubstitusi syarat awal $P\left(t_{0}\right)=P_{0}$ ke (2) sehingga menghasilkan

$\ln P_{0}=k t_{0}+C$

$\leftrightarrow C=\ln P_{0}-k t_{0}$

Kemudian disubstitusi nulai $\mathrm{C}$ tersebut ke (2) dan diperoleh

$\ln P=k t+\ln P_{0}-k t_{0}$

Persamaan terakhir ini dapat disederhanakan secara aljabar menjadi

$\ln P-\ln P_{0}=k t-k t_{0}$

$\leftrightarrow \ln \frac{P}{P_{0}}=k\left(t-t_{0}\right)$

Terakhir dengan mengeksponensialkan kedua ruas persamaan tersebut sehingga dapat ditulis

$\frac{P}{P_{0}}=e^{k\left(t-t_{0}\right)}$

$\leftrightarrow P(t)=P_{0} e^{k\left(t-t_{0}\right)}$

Jadi persamaan (3) merupakan solusi dari model (1) dan persamaan tersebut dikenal sebagai model pertumbuhan populasi Malthusian. Model pertumbuhan populasi tersebut memprediksi bahwa populasi bertambah secara eksponensial seiring dengan bertambahnya waktu.

\section{d) Verifikasi model}

Berikut akan dilakukan verifikasi model dengan mengambil contoh studi kasus pada populasi jumlah penduduk provinsi sumatera barat (SUMBAR). Sebagaimana diperoleh sebelumnya yaitu $\ln \frac{P}{P_{0}}=k\left(t-t_{0}\right)$ sehingga model pada persamaan (3) memprediksi bahwa jika diplot $\ln \frac{P}{P_{0}}$ versus $t-t_{0}$ maka diperoleh suatu garis lurus yang melalui titik asal $(0,0)$ dengan gradient $k$. Namun jika diplot berdasarkan data populasi penduduk SUMBAR untuk beberapa tahun, model tersebut tidak cocok khususnya pada tahun - tahun terakhir. Faktanya berdasarkan sensus penduduk
SUMBAR, tahun 1980 populasi penduduk SUMBAR 3.406.816 dan tahun 2000 populasinya 4.248.931. Dalam hal ini dimisalkan $P_{0}=3.406 .816$ untuk $t_{0}=1980$ sehingga berdasarkan persamaan (3) dapat dinyatakan sebagai

$$
\begin{aligned}
P(2000) & =3.406 .816 e^{k(2000-1980)} \\
& =4.248 .931 \\
\leftrightarrow & 1,247=e^{20 k} \\
\leftrightarrow \ln 1,247 & =\ln e^{20 k}=20 k
\end{aligned}
$$

Jadi diperoleh $k=\frac{\ln 1,247}{20}=\frac{0,221}{20} \approx 0,01 \quad$, artinya

Selama periode 20 tahun populasi penduduk di SUMBAR meningkat dengan laju rata- rata $1 \%$ pertahun.

Selanjutnya dari nilai $k$ yang diperoleh tersebut dan persamaan (3) dapat diprediksi populasi penduduk SUMBAR pada tahun 2010 yaitu

$$
\begin{aligned}
P(2010) & =4.248931 e^{0,01(2010-2000)} \\
& =4.695 .795
\end{aligned}
$$

Disisi lain sensus penduduk tahun 2010 menunjukkan jumlah populasinya sebesar 4.846.909. Dalam hal ini prediksi yang diperoleh meleset dengan error $3 \%$.

Dengan cara yang sama dilakukan prediksi penduduk ditahun 2018 sehingga diperoleh $P(2018)=5.0816 .894$, sedangkan sensusnya menunjukkan angka 5.511.246 dengan demikian errornya $7 \%$.

Selanjutnya prediksi beberapa tahun yang akan datang diperoleh hasil sebagai berikut:

a. Prediksi penduduk tahun 2030 yaitu $P(2030)=5.735 .457$

b. Prediksi penduduk tahun 2050 yaitu $P(2050)=7.005 .303$

c. Prediksi penduduk tahun 2100 yaitu $P(2100)=11.549 .791$

d. Prediksi penduduk tahun 2200 yaitu $P(2200)=31.395 .589$

e. Prediksi penduduk tahun 2300 yaitu $P(2300)=85.342 .060$ 
Dari hasil tersebut menunjukkan bahwa untuk jangka waktu panjang populasinya melebihi kapasitas area (daya tampung) yang ada, jadi hasil ini tidak masuk akal sehingga sebagai solusinya perlu dilakukan perbaikan model dengan pertumbuhan terbatas yaitu membatasi maksimun penduduknya sebesar $M$.

e) Perbaikan model

Misalkan konstanta proporsionalitas $k$ didefinisikan sebagai fungsi dari populasi. Ketika populasi bertambah dan mendekati jumlah maksimum populasi $M$, maka laju $k$ akan semakin kecil. Suatu submodel sederhana untuk $k$ adalah fungsi linear yang dapat ditulis sebagai berikut $k=r(M-P), r>0$ dimana $r$ suatu konstanta.

Dengan mensubstitusikan $\mathrm{k}$ ini ke persamaan (3) akan diperoleh model pertumbuhan logistik.

$\frac{d P}{d t}=r(M-P) P, P\left(t_{0}\right)=P_{0}$,

$t_{0} \leq t \leq t_{1}$

Model ini merupakan model pertumbuhan populasi dengan pertumbuhan terbatas yaitu dibatasi maksimum penduduknya sebesar $M$. Pertama kali model ini diperkenalkan oleh seoarang ahli biologi matematika Belanda Pierre - Franco Verhulse, $1804-1849$.

Dengan metode pemisahan variabel model $(u)$ dapat diselesaikan sebagai berikut,

$\frac{1}{P(M-P)} d P=r d t$

Secara aljabar persamaan diatas dapat ditulis sebagai

$\frac{1}{M}\left(\frac{1}{P}+\frac{1}{M . P}\right) d P=r d t$

$\leftrightarrow \frac{1}{P} d P+\frac{1}{M-P} d P=r M d t$
Kemudian diintegralkan kedua ruasnya sehingga

$\int \frac{1}{P} d P+\int \frac{1}{M-P} d P=\int r M d t$

$\leftrightarrow \ln P-\ln (M-P)=r M t+$

$C$ untuk suatu konstanta $C$

Dengan menggunakan syarat awal $P\left(t_{0}\right)=P_{0} \quad$ ke persamaan diatas, maka diperoleh $C$ untuk kasus $P<M$ sebagai berikut:

$$
\begin{aligned}
\ln P_{0}-\ln M-P_{0} & =r M t_{0}+C \\
\leftrightarrow \ln \frac{P_{0}}{M-P_{0}} & =r M t_{0}+C \\
\leftrightarrow C & =\ln \frac{P_{0}}{M-P_{0}}-r M t_{0}
\end{aligned}
$$

Selanjutnya nilai $C$ tersebut disubsitusikan ke persamaan (5) sehingga

$$
\begin{aligned}
& \ln P-\ln (M-P)=r M t+\ln \frac{P_{0}}{M-P_{0}}-r M t_{0} \\
& \leftrightarrow \ln \frac{P}{M-P}-\ln \frac{P_{0}}{M-P_{0}}=r M t-r M t_{0} \\
& \leftrightarrow \ln \frac{P\left(M-P_{0}\right)}{P_{0}(M-P)}=r M\left(t-t_{0}\right)
\end{aligned}
$$

Dengan mengeksponensialkan kedua ruasnya diperoleh

$$
\begin{aligned}
& \frac{P\left(M-P_{0}\right)}{P_{0}(M-P)}=e^{r M\left(t-t_{0}\right)} \\
& \leftrightarrow P_{0}(M-P) e^{r M\left(t-t_{0}\right)}=P\left(M-P_{0}\right) \\
& \leftrightarrow P_{0} M e^{r M\left(t-t_{0}\right)}=P\left(M-P_{0}\right)+P_{0} P e^{r M\left(t-t_{0}\right)} \\
& \quad=P\left(M-P_{0}+P_{0} e^{r M\left(t-t_{0}\right)}\right)
\end{aligned}
$$




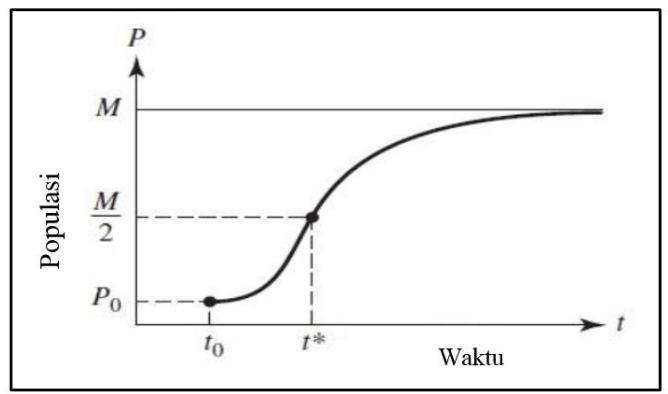

Gambar 1. Kurva Logistik Populasi Pertumbuhan Penduduk

Dari persamaan terakhir diperoleh solusi model pada persamaan (4) yaitu

$$
\begin{aligned}
& P(t)=\frac{P_{0} M e^{r M\left(t-t_{0}\right)}}{\left(M-P_{0}\right)+P_{0} e^{r M\left(t-t_{0}\right)}} \\
& \leftrightarrow P(t)=\frac{M P_{0}}{\left(M-P_{0}\right) e^{r M\left(t-t_{0}\right)}+P_{0}}
\end{aligned}
$$

Perhatikan bahwa pada persamaan (6) ketika $t$ Menuju tak hingga maka nila $P(t)$ akan mendekati $M$ atau ditulis $P(t) \rightarrow M$ ketika $t \rightarrow \infty$.

Selanjutnya dari persamaan (4) dihitung turunan keduanya sebagai berikut

$P^{\prime}=r(M-P) P=r M P-r P^{2}$

$\rightarrow P^{\prime \prime}=r M P^{\prime}-2 r P P^{\prime}=r P^{\prime}(M-2 P)$

Dari turunan kedua ini diperoleh $P^{\prime \prime}=$ 0 ketika $P=M / 2$ artinya populasi $P$ mencapai setengah dari batas maksimum populasi $M$ sehingga nilai $M$ dapat diperkirakan, kemudian dari hasil persamaan (6) dapat digambarkan pada Gambar 1 untuk kasus $P<M$, dimana kurva yang diperoleh disebut sebagai kurva logistik.

\section{KESIMPULAN}

Persamaan diferensial merupakan suatu persamaan matematika yang memuat satu atau lebih suku yang melibatkan turunan dari satu variabel terikat terhadap variabel - variabel bebasnya. Persamaan diferensial banyak digunakan dalam berbagai bidang ilmu seperti, fisika, biologi, ekonomi, teknik dan lainnya. Salah satu aplikasi persamaan diferensial dapat dilihat pada model pertumbuhan populasi dengan pertumbuhan terbatas. Kemudian dengan mengambil contoh studi kasus pada populasi penduduk SUMBAR dari model pertumbuhan Malthus yang di konstruksi diperoleh bahwa model ini tidak cocok untuk memprediksi populasi penduduk pada jangka waktu panjang karena populasi berkembang secara eksponensial. Sebagai solusi dilakukan perbaikan model tersebut menjadi model pertumbuhan populasi dengan pertumbuhan terbatas. Akhirnya diperoleh suatu model pertumbuhan logistic yang leih baik dari sebelumnya, model ini dapat digambarkan dalam bentuk kurva logistik.

\section{DAFTAR KEPUSTAKAAN}

Giordano, F. R., Fox, W. P., \& Horton, S. B. (2010). A first course in mathematical modeling. USA: Brooks/Cole.

Law, R., Murrell, D. J., \& Dieckmann, U. (2003). Population Growth in Space and Time: The Spatial Logistic Equation. Retrieved from www.iiasa.ac.at

Trench, W. F. (2013). Elementary Differential Equations with Boundary Value Problems. Trinity University.

Tsoularis, A., \& Wallace, J. (2002). Analysis of logistic growth models. Mathematical Biosciences Elsevier, 179(1), 21-25. 